\title{
ПОЧВЫ ПРОМЫШЛЕННЫХ ЗОН ГОРОДА ХАБАРОВСКА И ИХ БИОЛОГИЧЕСКАЯ АКТИВНОСТЬ
}

\author{
Росликова В. И. ${ }^{1}$, Матвеенко Т. И. ${ }^{2}$, Майорова Л. П. \\ ${ }^{\prime}$ ФББУН Институт водных и экологических проблем ДВО РАН, г. Хабаровск \\ E-mail: roslikova@ivep.as.khb.ru \\ ${ }^{2}$ ФББОУВО Тихоокеанский государственный университет, г. Хабаровск \\ E-mail: matveenkoti@mail.ru; 000318@pnu.edu.ru
}

\begin{abstract}
Городские почвы - это сложнейшая трансформированная система. Наиболее широкое распространение на территории города имеет техногенный литогенез, определяющий формирование новых отложений с различными свойствами. В работе применена субстантивно-генетическая классификация трансформированных почв и предпочвенных образований промышленных зон г. Хабаровск. В основу деления последовательности горизонтов положена классическая система АВС. При морфологическом описании разрезов внимание обращается на вновь образованные почвенные тела, сформированные на различных по генезису современных отложениях, а также их положение в элементарных ландшафтах. Показатели дыхательной активности и фитотоксичности почв позволяют судить об изменениях их биологической активности под действием техногенного пресса. Приведенные результаты исследований показали, что однозначной приуроченности дыхательной активности к почвенным образованиям не выявлено, в каждой промышленной зоне она обусловлена происхождением и свойствами техногенных отложений. Пространственное варьирование биологической активности значительное и, в целом, лежит в пределах ее низких значений. Полученные результаты свидетельствуют о необходимости выбора для каждой промышленной зоны конкретных ремедиационных мероприятий соответственно состоянию почвенного образования.
\end{abstract}

Ключевые слова: промышленные зоны, трансформированные почвы, дыхательная активность, фитотоксичность.

DOI: $10.34078 / 1814-0998-2021-2-77-86$

\section{ВВЕДЕНИЕ}

Почвенный покров урбанизированных ландшафтов в Приамурье характеризуется высокой степенью антропогенного изменения. В урбанизированных ландшафтах трансформация почв подразделяется на два типа: техногенную (воздействие строительно-промышленных комплексов и иных объектов) и агрогенную (сельскохозяйственное использование земель). В представленной работе авторы акцентировали внимание на трансформированных почвах и предпочвенных образованиях.

Изучение особенностей формирования состава и свойств урбанизированных почв является актуальной проблемой экологического почвоведения (Котлов, 1978; Герасимова и др., 2003; Безуглова и др., 2012). Ее решение важно для прогнозной и экологической оценки их состояния. Традиционно исследование почв города было на2021

( ) Росликова В. И., Матвеенко Т. И., Майорова Л. П., правлено на оценку их санитарного состояния, а также на выявление содержания в них различных загрязнителей (Горбов, 2002; Алексеев, 2008; Сорокина, 2013). В последние годы широко изучается ферментативная и биотическая активность почв (Filip, 2002; Умаров, 2003; Bastida et al., 2008; Шаркова и др., 2011; Горбов, Безуглова, 2013; Поляков, Ревуцкая, 2016; Paz-Ferreiro, Fu, 2016). Проводятся исследования фитотоксичности почв урбанизированных территорий (Шпис, 1999; Иващенко и др., 2014; Галактионова, Суздалева, 2017; Пудова, Шадрина, 2017; Ляпина и др., 2019). Однако следует отметить, что для урбанизированных ландшафтов в таких сложных природно-техногенных условиях, как Приамурье, к настоящему времени весьма ограничены сведения о биологической активности почв.

В соответствии с зональными условиями здесь сформировался типичный для этих ландшафтов почвенный покров (Росликова, Матвеенко, 2018). Антропогенная деятельность обусловила активизацию современных геологических про- 
цессов. Таковыми являются: эрозионные (речная, струйчатая и овражная эрозия); гравитационные (оползни, осыпи, обвалы); гидрогеологические (заболачивание, подтопление, суффозия, карст); техногенные (повышения или понижения рельефа, техногенный литогенез, разработка искусственных выемок и др.) (Подгорная, 2013).

Совокупность этих процессов приводит к формированию искусственных грунтов, преобра-

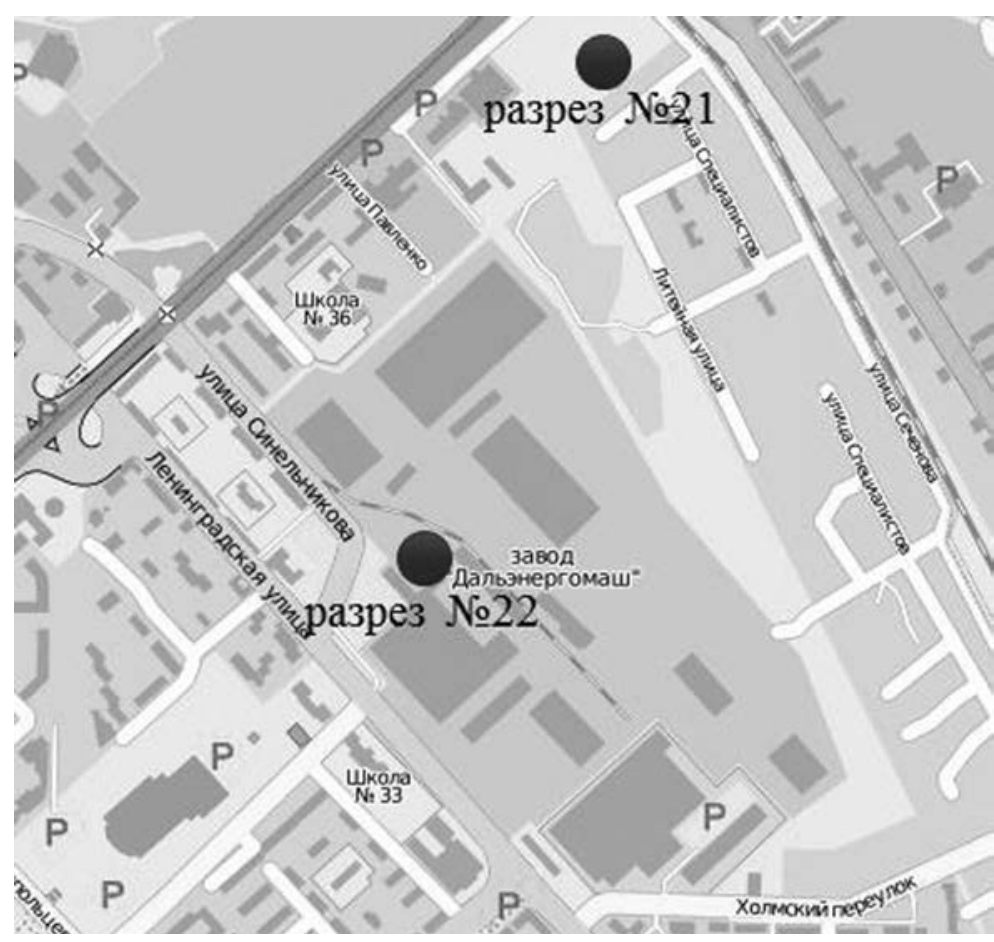

Зона влияния завода «Энергомаш»

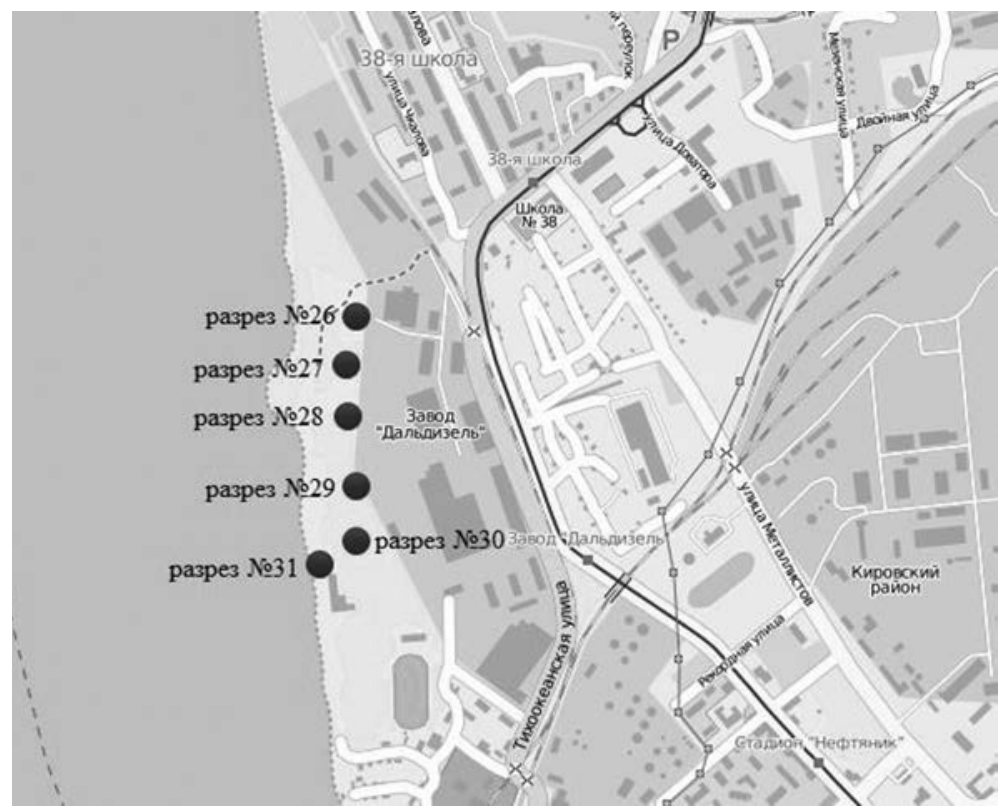

Район завода «Дальдизель»

Рuc. 1. Карто-схемы расположения почвенных разрезов Fig. 1. Map charts of soil section location зованию поверхностной гидросферы и трансформации почвенного покрова. Наиболее широко распространен на территории города техногенный литогенез, который определяет формирование новых отложений (Подгорная, Росликова, 1999), различающихся как по качественным, так и количественным характеристикам.

Методы биотестирования, основанные на ответной реакции живых организмов на негативное воздействие загрязняющих веществ, способны давать достоверную информацию о качестве компонентов окружающей среды, в том числе почв. Эти методы оценки имеют следующие преимущества: возможность получить интегральную токсикологическую характеристику почв независимо от качественного и количественного состава загрязняющих веществ; быстроту проведения анализа; доступность и простоту экспериментов; выявление динамичности процессов; достоверность и объективность полученных данных.

На основе проведенного анализа сформулирована цель исследований: дать оценку дыхательной активности и фитотоксичности трансформированных почв и почвоподобных образований в промышленных зонах г. Хабаровск.

Исследуемые показатели позволяют судить об изменениях биологической активности почв под действием антропогенного пресса и могут служить теоретической основой для разработки методов мониторинга состояния урбаноземов. Дыхание почвы представляет собой сложное, многофункциональное природное явление, проявляющееся в процессах газообмена между основными компонентами почв (органическое вещество, биомасса живых организмов). Оно хорошо характеризует микробиологическую активность, о которой можно судить по количеству выделенного углекислого газа - продукта жизнедеятельности микроорганизмов (Стефурак и др., 1990; Горбов, Безуглова, 2013; Иващенко и др., 2014; Поляков, Ревуцкая, 2016).

\section{ОБЪЕКТЫ И МЕТОДЫ}

Образцы вновь образованных почвоподобных тел и трансформированных почв были отобраны в двух промышленных зонах города с различными литолого-геоморфологическими условиями (рис. 1). 
Территории фактически представляют собой зоны ранее накопленного экологического вреда. Описано 8 разрезов - № 21, 22, 26, 27, 28, 29-А, 30,31 . Детальное описание разрезов с их фотографиями приведено в монографии (Росликова, Матвеенко, 2018).

Применялись широко используемые в науках о Земле и почвоведении методы: литолого-геоморфологический, профильно-генетический, морфологический, физико-химический. Определение дыхательной активности проводилось по методу Э. А. Головко (1971). Суть метода заключается в том, что чем больше углекислого газа выделяется исследуемым объектом, тем выше активность жизнедеятельности почвенных микроорганизмов. Фитотоксичность исследовали по утвержденной методике (Методические.., 2008). В качестве модельного тест-растения использовали семена овса, которые дают наиболее стабильные и воспроизводимые данные по сравнению с семенами других культур.

В работе применена субстантивно-генетическая классификация. В основу выделения последовательности горизонтов положена классическая система АВС. Для отражения специфики горизонтов использованы конкретные предложения по обозначению признаков генетической сущности почв (Классификация..., 1977, 2004; Полевой..., 2008).

\section{РЕЗУЛЬТАТЫ И ОБСУЖДЕНИЕ}

При исследованиях особое внимание обращается на вновь образованные почвенные тела, сформированные на различных по генезису современных отложениях, а также их положение в элементарных ландшафтах. Ниже приведены морфологические описания разрезов.

Первая промышленная зона завода «Дальэнергомаш» расположена на пологоволнистой поверхности, сложенной плейстоценовыми озерноаллювиальными глинами. В результате производственной деятельности на них сформировались субаэральные шлаково-зольные отходы.

Разрез 21. Расположен с северной части завода на пологом участке овражно-балочной сети бывшего русла р. Плюснинка. Поверхность покрыта шлаково-зольными отходами. Поросль тополя, клена, в напочвенном покрове разнотравье. Профиль: IUTCH cn, a $\rightarrow 2 \mathrm{UTCH} \mathrm{cn,} \mathrm{a2} \rightarrow$ 3UTCH cn, a3. Предпочвенное образование - ичинозем золошлаковый на «бурых глинах».

Разрез 22. В 200 м северо-восточнее от непосредственного прямого воздействия промышленных отходов завода «Дальэнергомаш». Откос придорожной насыпи из переотложенных естественных суглинистых грунтов. Разреженный древостой вяза, в напочвенном покрове полынь, молочай, клевер, пырей. Профиль: $\mathrm{Au}$ a $1 \rightarrow$ UTCX, a2 $\rightarrow$ 2UTCX(Eg n), a2 $\rightarrow 3$ UTCX(Eg $\mathrm{nn}), \mathrm{a} 2 \rightarrow \mathrm{C}$. Предпочвенное образование - урбалитострат с фрагментами текстурно-дифференцированной почвы.

Вторая промылиленная зона охватывает территорию старейшего предприятия завода «Дальдизель». Здесь более чем за 100-летний период существования на крутом правобережье Амура изменилась устойчивость берегового склона, что обусловлено длительностью техногенного воздействия (нагрузки от сооружений, пригрузки склонов насыпями и свалками, сброс сточных вод в овраги). Данные процессы привели к формированию техногенных оползней. Почвенный покров изучали в различных частях оползневого массива с учетом сложного состава и многоярусного строения оползневых отложений, характеризующихся двумя блоками - природно-минеральным и техногенным, в которых преобразование толщ идет не однозначно. Наиболее характерными трансформированными почвами и предпочвенными образованиями в минеральном и техногенном блоках оползня являются следующие разновидности.

\section{Природно-минеральный блок:}

Разрез 26. Автономное положение. Освоенный участок берегового склона р. Амур вдоль его подрезки. Бывшая пашня. Разреженный древостой: черная береза, дикая груша, посадки войлочной вишни. В напочвенном покрове полынь, горец, бобовые. Профиль: $\mathrm{O} \rightarrow \mathrm{Ad} \rightarrow$ $\mathrm{PY}(\mathrm{B} 1)$ agr $\rightarrow \mathrm{B} 1$ (AY tr) $\rightarrow \mathrm{B} 1 \mathrm{CLM} \rightarrow \mathrm{B} 2 \mathrm{CM} \rightarrow$ CLM. Почва - бурозем постагрогенный турбированный на элюво-делювии глинистых сланцев.

Разрез 29- $A$. Аккумулятивное положение. Западная часть блокового сдвига, повышенный участок. Заросли широколиственных пород и мелколиственных, шиповник, леспедеца, сухолюбивое разнотравье. Профиль: $\mathrm{O} \rightarrow \mathrm{A} 1 \rightarrow \mathrm{B} / \mathrm{C}$ str $\rightarrow \mathrm{C}$. Почва - бурозем стратифицированный на оползневых минеральных отложениях.

\section{Техногенный блок:}

Разрез 27. Транзитно-аккумулятивное положение. Оползневая западина шириной около 20 м. По окраине вязы, ясень, береза, в напочвенном покрове хвощ, тростник, молочай. Профиль: Amb $\rightarrow$ IXR agu, str, a IXU Ragu, str $\rightarrow$ 2XR agu, str, a2. Предпочвенное образование - хемозем пирогенный (амбустированный) аквастратифицированный на перемещзенных техногенных отложениях. 
Разрез 28. Ровный участок. Выход на поверхность техногенно-сбросовых вод черно-маслянистого характера. Растительность - вяз, возобновление ивы, тростник. Профиль: O $\rightarrow$ IXRU agu, stra2 $\rightarrow$ XXRU agu, stra3 $\rightarrow$ RRU agu, stra. Предпочвенное образование - хемозем аквастратифицированный на перемещенных техногенных отложениях.

\section{Аккумулятивная часть техногенного оползня:}

Разрез 30. Западный склон эрозионного уступа с мелкобугристой поверхностью. Оползневые техногенные отложения мощностью до 2 м с включением строительных отходов. На повышенных участках отдельно стоящие деревья дуба, на пониженных - тростник. Профиль: $\mathrm{Oa} \rightarrow \mathrm{IUru}, \mathrm{a} 2 \rightarrow \mathrm{IIUru}, \mathrm{a} 1 \rightarrow \mathrm{IIIUru}$, a3. Предnoчвенное образование - рудизем на перемещенных техногенных отложениях.

Разрез 31. Распадок на языке оползня, береговая линия Амура. По повышенным участкам древостой тополя, бобовые, осока. Понижения заняты камышом. Профиль: 1 Ustr, a1 $\rightarrow 2$ Ustr, a3. Предпочвенное образование - стратозем на перемещенных техногенных отложениях.

Как следует из морфологического описания, новые почвенные образования фиксируют признаки (свойства) тех отложений, на которых они сформировались. Так, для первой промышленной зоны характерен цинозем, сформированный на субаэральных золошлаковых отложениях. Он отличается обилием шлакового и зольного материала по всему профилю (разрез 21). Находящийся в 200 м от цинозема профиль урбалитострата (разрез 22) на искусственно созданной насыпи состоит из переотложенных естественных суглинистых грунтов с погребенными линзами урбанизированной текстурно-дифференцированной почвы.

Вторая промышленная зона с широко развитыми склоновыми процессами представлена двумя блоками: природно-минеральным и вложенным в него техногенным. Для природноминерального блока в автономных положениях характерно формирование бурозема постагрогенного турбированного (на глинистых сланцах). Верхняя толща агротурбирована с включением линз нижележащего горизонта. В аккумулятивной части рассматриваемого блока почвенный профиль бурозема полностью разрушен. На его месте сформировалось фрактально-стратифицированное (fraktus раздробленный) почвенное образование на минеральных оползневых отложениях. Оно представляет собой слои природных бурых легких суглинков с хаотичным включением раздроб- ленного щебня (с остроугольными гранями) осадочных пород.

Техногенный блок оползня - трансаккумулятивные положения отличаются скоплением производственных отходов в виде черной маслянистой «формовой земли», постоянно подтапливаемых темными маслянистыми техногенными водами. В этих условиях формируются хемоземы аквастратифицированные на перемещенных техногенных отложениях. На языке оползня в аккумулятивном положении, на отходах строительного производства, формируются рудиземы. Их профиль отличается наличием включений битума, цемента, стекла и иных инородных тел (артефактов).

Во всех трансформированных почвах и новых предпочвенных образованиях исследовали биологическую активность (см. таблицу).

«Фитотест» основан на способности семян адекватно реагировать на экзогенное химическое воздействие путем изменения интенсивности прорастания корней. Это позволяет принять за показатель тест-функции их длину. Сравнение длины корней овса в исследуемых образцах с контролем показало, что их величина колеблется в широких пределах. В промышленной зоне завода «Энергомаш» разрезы 21 и 22 располагаются на разных техногенных отложениях, что проявляется в различии ростовых качеств овса в водных вытяжках почвенных проб. Так, в образцах нижней части профиля разреза 21 , приуроченного к золошлаковым отложениям, отмечается увеличение длины корней по сравнению с контролем на $44 \%$. Эта часть профиля до $40 \%$ состоит из золошлаковых отходов, из которых могут поступать стимулирующие вещества в водную вытяжку.

В разрезе 22, сформированном на перемещенных минеральных грунтах, проявляется противоположная тенденция распределения роста корней овса. Здесь, по сравнению с контролем, в пробах верхней части профиля длина корней овса достигает максимума 150 мм, что на 74 \% превышает длину корня контроля. Это обусловлено наличием в верхнем горизонте темно-гумусового пылеватого материала с обилием мелких корней, включений линз бытовых отходов. Реакция среды слабощелочная. Нижние части профиля отличаются включениями гравия, стекла, линз элювиально-глеевого горизонта тестурно-дифференцированных почв, пластинчатой структурой, и в этих условиях длина корней овса в пробах на 29-42 мм меньше средней величины корня контроля. Различия в структуре горизонтов определяют и содержание питательных (токсичных) веществ в водных вытяжках. 
Таблица. Общие данные биологической активности трансформированных почв промзоны

Table. General data on the biological activity of the transformed soils in the industrial zone

\begin{tabular}{|c|c|c|c|c|c|c|c|c|}
\hline \multirow[t]{2}{*}{ Горизонт } & \multirow[t]{2}{*}{ Глубина, см } & \multirow[t]{2}{*}{$\mathrm{pH}$} & \multicolumn{2}{|c|}{$\begin{array}{l}\text { Средняя } \\
\text { длина } \\
\text { корней, мм }\end{array}$} & \multirow{2}{*}{$\begin{array}{c}\text { Фито- } \\
\text { эффект } \\
\left(\mathrm{E}_{\mathrm{T}}\right), \%\end{array}$} & \multirow{2}{*}{$\begin{array}{l}\text { Тест-реакция } \\
\text { (эффект) }\end{array}$} & \multirow{2}{*}{$\begin{array}{c}\text { Скорость } \\
\text { эмиссии }\left(\mathrm{CO}_{2}\right. \\
\text { мг/10 г почвы) }\end{array}$} & \multirow{2}{*}{$\begin{array}{c}\text { Актив- } \\
\text { ность } \\
\text { почвы }\end{array}$} \\
\hline & & & $L_{\kappa}$ & $L_{o n}$ & & & & \\
\hline \multicolumn{9}{|c|}{ Зона завода «Энергомаш» } \\
\hline \multicolumn{9}{|c|}{ Цинозем золошлаковый на «бурых глинах», разрез 21} \\
\hline IUTCH cn, a & $0-37$ & 7.50 & 86 & 80 & 6.9 & \multirow{3}{*}{$\begin{array}{c}\text { Фитотоксический } \\
\text { эффект } \\
\text { отсутствует } \\
\end{array}$} & 1.71 & \multirow{3}{*}{$\begin{array}{c}\text { Очень } \\
\text { слабая } \\
\text { Слабая } \\
\end{array}$} \\
\hline 2UTCH cn, a2 & $37-61$ & 7.95 & & 96 & 0 & & 1.70 & \\
\hline 3UTCH cn, a3 & $61-80$ & 7.93 & & 130 & 0 & & 8.95 & \\
\hline \multicolumn{9}{|c|}{ Урбалитострат с погребенными линзами ТДП на переотложенных природных грунтах, разрез 22} \\
\hline Au a1 & $0.2-14$ & 7.70 & \multirow{4}{*}{86} & 150 & 0 & \multirow{2}{*}{$\begin{array}{c}\text { Фитотоксический } \\
\text { эффект } \\
\text { отсутствует }\end{array}$} & 2.07 & $\begin{array}{l}\text { Очень } \\
\text { слабая }\end{array}$ \\
\hline UTCX, a2 & $14-32$ & 6.27 & & 91 & 0 & & 14.80 & Средняя \\
\hline 2UTCX(Eg n), a2 & $32-77$ & 5.75 & & 48 & 44.2 & \multirow{2}{*}{$\begin{array}{c}\text { Средний } \\
\text { фитотоксический } \\
\text { эффект }\end{array}$} & 6.54 & Слабая \\
\hline 3UTCX(Eg nn), a2 & $130-140$ & 5.94 & & 57 & 33.7 & & 4.86 & $\begin{array}{l}\text { Очень } \\
\text { слабая }\end{array}$ \\
\hline \multicolumn{9}{|c|}{ Зона завода «Дальдизель» } \\
\hline \multicolumn{9}{|c|}{ Бурозем постагрогенный турбированный на элюво-делювии глинистых сланцев, разрез 26} \\
\hline PY(B1) agr & $1-25$ & 6.58 & \multirow{4}{*}{86} & 69 & 19.7 & $\begin{array}{c}\text { Слабый } \\
\text { фитотоксический } \\
\text { эффект }\end{array}$ & 5.88 & Слабая \\
\hline B1(AY tr) & $25-35$ & 5.96 & & 90 & 0 & Фитотоксический & 2.07 & \multirow{3}{*}{$\begin{array}{l}\text { Очень } \\
\text { слабая }\end{array}$} \\
\hline B1CLM & $35-45$ & 6.08 & & 83 & 4.7 & $\begin{array}{c}\text { эффект } \\
\text { отсутствует }\end{array}$ & 2.42 & \\
\hline B2CM & $45-70$ & 6.23 & & 60 & 30.2 & $\begin{array}{c}\text { Средний } \\
\text { фитотоксический } \\
\text { эффект }\end{array}$ & 1.38 & \\
\hline \multicolumn{9}{|c|}{$\begin{array}{c}\text { Хемозем пирогенный (амбустированный) аквастратифицированный на перемещенных техногенных } \\
\text { отложениях, разрез } 27\end{array}$} \\
\hline $\mathrm{Amb}$ & $0-2$ & - & \multirow[b]{2}{*}{86} & - & - & - & - & - \\
\hline IXR agu, str,a & $2-35$ & 6.95 & & 12 & 86.1 & $\begin{array}{c}\text { Недопустимая } \\
\text { фитотоксичность }\end{array}$ & 6.57 & Слабая \\
\hline \multicolumn{9}{|c|}{ Хемозем аквастратифиичиованный на перемещенных техногенных отложениях, разрез 28} \\
\hline IXRU agu, stra2 & $0-28$ & 7.01 & \multirow{3}{*}{86} & 65 & 24.4 & $\begin{array}{c}\text { Слабый } \\
\text { фитотоксический } \\
\text { эффект }\end{array}$ & 12.45 & Слабая \\
\hline 2XRU agu, stra3 & $28-40$ & 7.13 & & 82 & 4.7 & \multirow{2}{*}{$\begin{array}{c}\text { Фитотоксический } \\
\text { эффект } \\
\text { отсутствует } \\
\end{array}$} & 4.49 & $\begin{array}{l}\text { Очень } \\
\text { слабая }\end{array}$ \\
\hline 3RU agu, stra & $40-70$ & 7.32 & & 91 & 0 & & 6.57 & Слабая \\
\hline \multicolumn{9}{|c|}{ Бурозем стратифицированный на оползневых минеральных отложениях, разрез 29-А } \\
\hline $\mathrm{O}$ & $0-1.5(2)$ & - & - & - & - & - & - & - \\
\hline A1 & $1.5(2)-18$ & 7.95 & \multirow[b]{2}{*}{86} & 116 & 0 & \multirow{2}{*}{$\begin{array}{c}\text { Фитотоксический } \\
\text { эффект } \\
\text { отсутствует }\end{array}$} & 5.19 & \\
\hline $\mathrm{B} / \mathrm{C}$ str & $18-30$ & 6.98 & & - & 0 & & 8.30 & Слабая \\
\hline & Рудизем & nep & иеше & $\operatorname{lblxm}$ & огеннbl. & тложениях, разрез & 30 & \\
\hline IUru, a2 & $0-50$ & 7.88 & 86 & 99 & 0 & $\begin{array}{c}\text { Фитотоксический } \\
\text { эффект } \\
\text { отсутствует }\end{array}$ & 12.79 & Средняя \\
\hline & Стратоз & на ne & el & Hblx & $\mathrm{HOzeH}$ & отложениях, разр & 31 & \\
\hline 1Ustr, a1 & $0-40$ & 8.26 & & 83 & 3.5 & Фитотоксический & 0.34 & Очень \\
\hline 2Ustr, a3 & $40-90$ & 8.72 & 86 & 109 & 0 & $\begin{array}{c}\text { эффект } \\
\text { отсутствует }\end{array}$ & 1.04 & слабая \\
\hline
\end{tabular}

В пробах верхних горизонтов почвенных образований завода «Дальдизель», сформированных на склоновых отложениях (как техногенных, так и минеральных), прослеживается варьирование значений длины корней овса (рис. 2).
Наибольшая доля прироста корней характерна для проб аккумулятивного горизонта бурозема стратифицированного (разрез 29-А), составляя $42 \%$ от контрольной величины (86 мм). Реакция среды нейтральная, небольшая лесная подстилка 


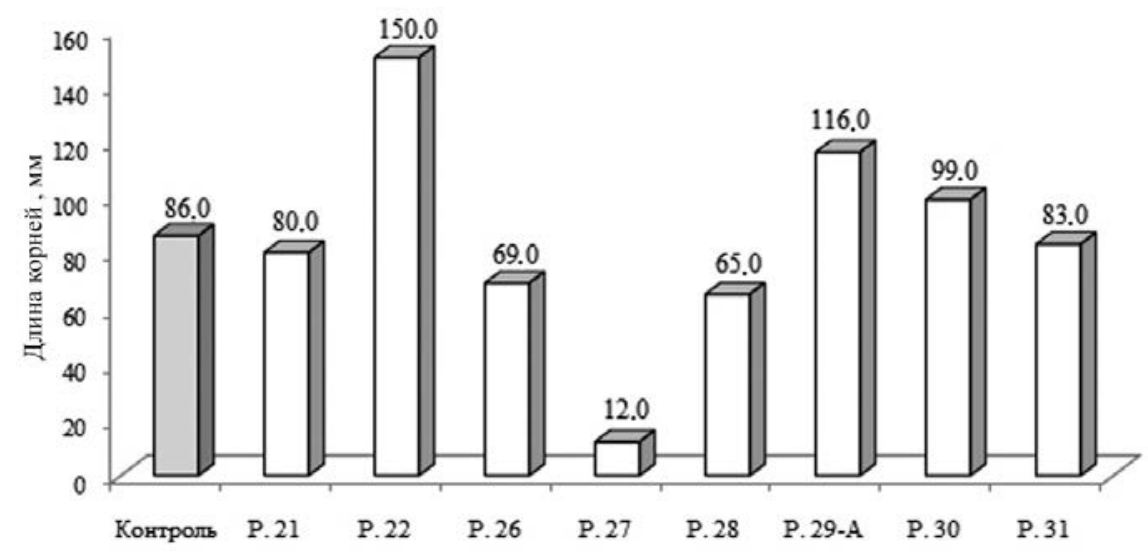

Рис. 2. Распределение длины корней овса в водных вытяжках проб из верхних слоев почвенных образований

Fig. 2. Distribution of oat root lengths in soil-water extract-samples from the upper layers of soil formations

поставляет определенную долю органики (горизонт А1 светло-серых тонов), легкий гранулометрический состав. Эти свойства обеспечивают в определенной мере благоприятные условия. Самая низкая длина корней овса выявлена в водных вытяжках из проб хемозема пирогенного аквастратифицированного на перемещенных техногенных отложениях (разрез 27). Здесь эта величина оказалась на 74 мм меньше контроля, что обусловлено наличием пирогенных процессов, которые уничтожили органическую часть в аккумулятивной толще. Кроме того, зона разреза находится под постоянным воздействием темных маслянистых «техногенных вод», химический состав которых, видимо, не благоприятствует условиям роста растений, проявившихся недопустимой фитотоксичностью (см. таблицу) (Ткаченко и др., 2013).

Длина корней овса в пробах может составлять от 5-30 до 115-131\% по сравнению с контролем. Такая пестрота полученных результатов полностью обусловлена неоднородностью техногенных толщ и возможностью накопления веществ в водных вытяжках.

Весьма важным показателем является скорость эмиссии $\mathrm{CO}_{2}$, свидетельствующая об условиях функционирования микробного сообщества. Оценку биологической активности исследователи в основном сосредотачивают на ее изучении в аккумулятивных горизонтах. Это обусловлено тем, что из-за наличия здесь основных запасов органического вещества микробные процессы наиболее активны (Гапонюк, Малахов, 1985). В связи с тем, что исследуемые объекты не имеют генетических горизонтов и в основном представлены слоями техногенных грунтов, были изучены не только верхние, но и в отдельных разновидностях трансформированных почв и предпочвенных образований нижележащие слои.
Опираясь на шкалу сравнительной оценки биологической активности почвы (Казеев и др., 2004), следует отметить, что скорость эмиссии $\mathrm{CO}_{2}$ в пробах почвенных образований всех зон лежит в пределах очень слабой (0-5 $\mathrm{CO}_{2}$ мг/10 г) и слабой (5-10 $\mathrm{CO}_{2}$ мг/10 г) биологической активности (см. таблицу; рис. 3).

Очень слабой эмиссией отличаются цинозем золошлаковый (разрез 21), бурозем постагрогенный турбированный (разрез 26), хемозем аквастратифицированный (разрез 28), стратозем на перемещенных техногенных отложениях (разрез 31). В них выделение $\mathrm{CO}_{2}$ колеблется в пределах 0.34-4,8 мг/10 г. И только в двух разрезах (разрез 22 и 30) на различных глубинах этот показатель едва достигает средней активности - соответственно около 14.8 и $12.8 \mathrm{CO}_{2}$ мг/10 г. Важно отметить тот факт, что в исследуемых нами объектах распределение дыхательной активности по профилю не имеет закономерности, установленной для почв (снижения с глубиной). На фоне общей слабой биологической активности некоторое повышение ее имеет место не только в верхнем аккумулятивном горизонте. Такая пестрота данных обусловлена природой как самих техногенных отложений, так и наличием в них различного рода включений.

При рассмотрении кислотности почвенных горизонтов установлено, что они имеют реакцию среды от нейтральной до щелочной и слабощелочной (см. таблицу), не свойственную природным почвам (кислые и слабокислые). Тесной связи между $\mathrm{pH}$ и дыхательной активностью почв промышленных зон не прослеживается. Угнетение активности микроорганизмов связано не только со смещением реакции среды в щелочную сторону, но и с другими факторами, в том числе происхождением почвоподобных тел. 


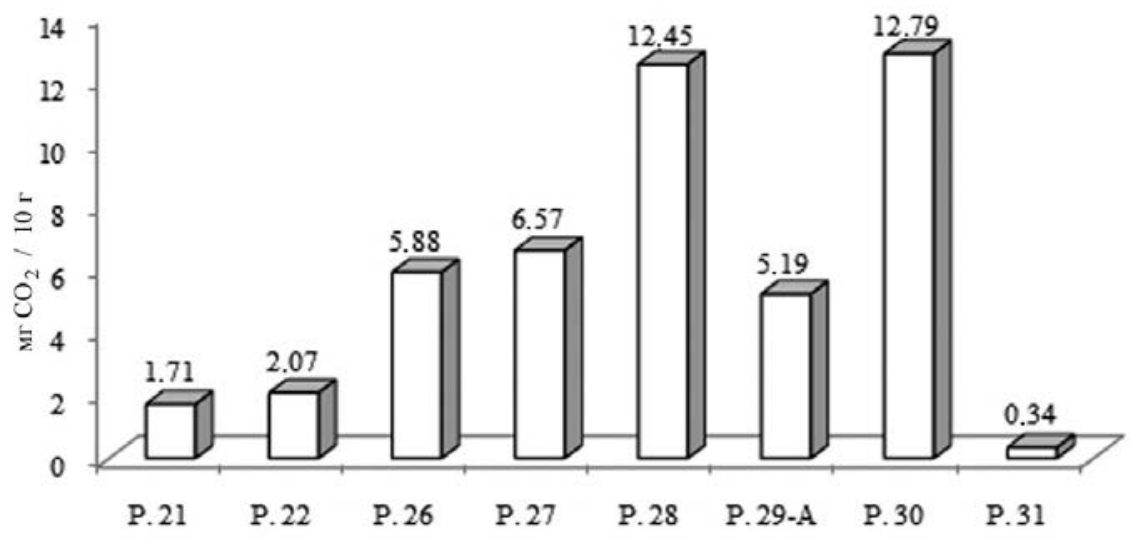

Puc. 3. Активность биоты в пробах из верхних слоев почвенных образований промышленных зон

Fig. 3. Biota activity in samples from the upper layers of soil formations in industrial zones

\section{ЗАКЛЮЧЕНИЕ}

Исследования, проведенные в двух промышленных зонах г. Хабаровск, показали, что там сформировались антропогенно-измененные почвы и новые предпочвенные образования, многоликость которых обусловлена различными литолого-геоморфологическими условиями освоенной территории города, а также влиянием различных производственных отходов, на которых соответственно образовались тела. Минимальный прирост корневой системы овса (отрицательный эффект или недопустимая фитотоксичность) проявился только в образцах хемозема пирогенного аквастратифицированного на перемещенных техногенных отложениях (разрез 27). Наибольшая доля прироста корней овса (42 \%) характерна для аккумулятивного горизонта бурозема стратифицированного (разрез 29-А). Изменения данного показателя по глубине четких закономерностей не имеет. Дыхательная активность в каждой промышленной зоне обусловлена происхождением и свойствами техногенных отложений. Пространственное варьирование биологической активности значительное и лежит в пределах низких ее значений. Очень слабой величиной эмиссии отличаются цинозем золошлаковый (разрез 21), бурозем постагрогенный турбированный (разрез 26), хемозем аквастратифицированный (разрез 28), стратозем на перемещенных техногенных отложениях (разрез 31). Полученные результаты свидетельствуют о необходимости выбора для каждой промышленной зоны конкретных ремедиационных мероприятий соответственно состоянию почвенного образования.

\section{ЛИТЕРАТУРА}

Алексеев Ю. В. Тяжелые металлы в агроландшафте. Санкт-Петербург : Изд-во ПИЯФ РАН, 2008. $216 \mathrm{c}$.
Безуглова О. С., Горбов С. Н., Морозов И. В., Невидомская Д. Г. Урбо-почвоведение. Ростов-на-Дону : Изд-во Южного федеральн. ун-та, 2012. 264 с.

Галактионова Л. В., Суздалева А. В. Экологическая оценка почвенного покрова урбанизированных территорий методами биодиагностики [Электрон. pecypc]. URL : https://science-education.ru/ru/article/ view?id=26560 (дата обр. 01.09.2020).

Гапонюк Э. И., Малахов С. Г. Комплексная система показателей экологического мониторинга почв. Миграция загрязняющих веществ в почвах и сопредельных средах. Ленинград : Гидрометеоиздат, $1985.256 \mathrm{c}$.

Герасимова М. И., Строганова М. Н., Можарова Н. В., Прокофьева Т. В. Антропогенные почвы: генезис, география, рекультивация / под ред. Г. В. Добровольского. Смоленск : Ойкумена, 2003. $268 \mathrm{c}$.

Головко Э. А. О методах изучения биологической активности торфяных почв // Материалы науч. конф. по методам микробиологических и биохимических исследований почв. Киев, 28-31 окт. Киев, 1971. С. 68-76.

Горбов С. Н. Почвы урбаландшафтов г. Ростов-наДону, их экологическое состояние и оценка загрязнения : дис. ... канд. биол. наук. Ростов-на-Дону, 2002. 215 с.

Горбов С. Н., Безуглова О. С. Биологическая активность почв городских территорий (на примере г. Ростов-на-Дону) // Научный журнал КубГАУ. 2013. № 85. С. 1-15.

Иващенко К. В., Ананьева Н. Д., Васенев В. И. Кудеяров В. Н., Валентини Р. Биомасса и дыхательная активность почвенных микроорганизмов в антропогенно-измененных экосистемах (Московская область) // Почвоведение. 2014. № 9. С. 10771088.

Казеев К. Ш., Колесников С. И., Вальков В. Ф. Биология почв Юга России. Ростов-на-Дону : Изд-во «ЦВВР», 2004. 350 c.

Классификация и диагностика почв России / сост. Д. Л. Шишов, В. Д. Тонконогов, И. И. Лебедева. Москва : Почвенный ин-т им. В. В. Докучаева РАСХН, 2004. 342 c. 
Классификащия и диагностика почв СССР. Москва : Колос, 1977. 224 с.

Котлов Ф. В. Изменение геологической среды под влиянием деятельности человека. Москва : Недра, $1978.263 \mathrm{c}$.

Ляпина Н. Ш., Мясникова И. Б., Усова Л. С., Колосов $E$. C. Определение фитотоксичности почв как метод оценки ее загрязнения // Сб. статей II Всерос. науч. практ. конф. 2019. Ч. 1. С. 257-260.

Методические рекомендации / МР 2.1.7.2297-07 / Почва. Очистка населенных мест. Бытовые и промышленные отходы. Санитарная охрана почвы // Бюллетень нормативных и методических документов Госсанэпиднадзора. 2008. Вып. 1 (31). 13 с.

Подгорная Т. И. Опасные природно-техногенные геологические процессы на освоенной территории Дальнего Востока России. Хабаровск : Изд-во Тихоокеан. гос. ун-та, 2013. 285 с.

Подгорная Т. И., Росликова В. И. Влияние техногенных геологических процессов на современное почвообразование в городах Дальнего Востока. Владивосток : Дальнаука, 1999. 75 с.

Полевой определитель почв России. Москва : Почвенный ин-т им. В. В. Докучаева РАСХН, 2008. $182 \mathrm{c}$.

Поляков В. Ю., Ревуичкая И. Л. Ферментативная активность верхних диагностических горизонтов городских антропогенных почв Биробиджана // Вестник Оренбургского государственного университета. 2016. № 1 (189). C. 95-99.

Пудова Т. М., Шадрина Е. Г. Биотестирование загрязнения почвенного покрова урбанизированных территорий по показателям всхожести и мутагенной активности лука-батуна Allium fistulosum L. (на примере г. Якутска) [Электрон. peсурс]. URL: https:// science-education.ru/ru/article/view?id=26346 (дата обр. 01.09.2020).
Росликова В. И., Матвеенко Т. И. Урбанизированные почвы Приамурья (на примере г. Хабаровска). Хабаровск : Изд-во ТОГУ, 2018. 224 с.

Сорокина О. И. Тяжелые металлы в ландшафтах г. Улан-Батора : автореф. дис. ... канд. геогр. наук. Москва, 2013. 26 с.

Стефурак В. П., Усатая А. С., Фрунзе Н. И., Катрук Э. А. Ферментативная активность почв в условиях антропогенного воздействия. Кишинев : Изд-во Кишинев. ун-та, 1990. 214 с.

Ткаченко Я. Д., Поспелова О. А, Степаненко Е. Е. Биотестирование загрязнения почв промышленных зон г. Ставрополя [Электрон. pecypc]. URL: http://ores. su/index.php/-1132013/352-2013-02-25-07-51-41 (дата обр. 01.09.2020).

Умаров М. М. Роль микроорганизмов в круговороте химических элементов в наземных экосистемах. Структурно-функциональная роль почвы в биосфере. Москва : Наука, 2003. С. 125-139.

Шаркова С. Ю., Парфенова Е. А., Полянскова Е. А. Биоиндикация городской среды по состоянию микробного комплекса почв // Экология и промышленность России. 2011. № 11. С. 44-47.

Шnис T. Э. Фитотоксичность почв, факторы ее формирования и реакция различных культур на загрязнение почв тяжелыми металлами в условиях степной зоны Алтайского края : автореф. дис. ... канд. с/х наук. Барнаул, 1999. 22 с.

Bastida F., Zsolnay A., Hernández T., García C. Past, present and future of soil quality indices: a biological perspective // Geoderma. 2008. 147. 159-171.

Filip Z. International approach to assessing soil quality by ecologically-related biological parameters // Agriculture, Ecosystems and Environment. 2002. 88. 169-174.

Paz-Ferreiro Jorge, Fu Shenglei. Biological indices for soil quality evaluation: perspectives and limitations // Land degradation and development. 2016. 27. 14-25.

Поступила в редакиию 02.03.2021 г.

Поступила после доработки 03.04.20212.

\title{
SOILS OF INDUSTRIAL ZONES IN THE CITY OF KHABAROVSK AND THEIR BIOLOGICAL ACTIVITY
}

\author{
V. I. Roslikova ${ }^{1}$, T. I. Matveenko ${ }^{2}$, L. P. Mayorova ${ }^{2}$ \\ ${ }^{1}$ Institute of Water and Environmental Problems, FEB RAS, Khabarovsk \\ ${ }^{2}$ Pacific National University, Khabarovsk
}

Urban soils are a complex transformed system. The most widespread over the the city area is technogenic lithogenesis, which determines the formation of new deposits with different properties. The researchers use the substantial genetic classification of trasformed soils and soil formations in industrial zones of the city of Khabarovsk. The basis for the selection of the horizon sequence is the classical $\mathrm{ABC}$ system. In the morphological description of the sections, attention is drawn to the newly formed soil bodies formed on modern deposits of different genesis, as well as to their position in elementary landscapes. Indicators of respiratory activity and phytotoxicity of soils permit to consider changes in their biological activity under the anthropogenic pressure. The research results presented have shown that there is no firm attribution of respiratory activity to soil formations in industrial zones; in each industrial zone, 
it is due to the functional type of sediments. The spatial variation of biological activity is significant and, in general, lies within its low values. The results obtained indicate the need to select specific remediation measures for each industrial zone, according to the soil formation state.

Keywords: industrial zones, transformed soils, respiratory activity, phytotoxicity.

\section{REFERENCES}

Alekseyev, Yu. V., 2008. Heavy Metals in the Agricultural Landscape. St. Petersburg, Russian Academy of Sciences [In Russian].

Bastida, F., Zsolnay, A., Hernández, T., García, C., 2008. Past, Present and Future of Soil Quality Indices: a Biological Perspective, Geoderma. 147, 159-171.

Bezuglova, O. S., Gorbov, S. N., Morozov, I. V., Nevidomska, D. G., 2012. Urban Soil Science. Rostov-onDon, Southern Federal University [In Russian].

Classification and Diagnostics of Soils in Russia, 2004. Compiled by D. L. Shishov, V. D. Tonkonogov, I. I. Lebedeva. Moscow, V. V. Dokuchaev Soil Science Institute [In Russian].

Classification and Diagnostics of Soils of the USSR, 1977. Moscow, Kolos [In Russian].

Field Determinant of Soils in Russia, 2008. Moscow, Soil Institute V. V. Dokuchaev RASKHN [In Russian].

Filip, Z., 2002. International Approach to Assessing Soil Quality by Ecologically-Related Biological Parameters, Agriculture, Ecosystems and Environment. 88, 169174.

Galaktionova, L. V., Suzdaleva, A. V., 2020. Ecological Assessment of the Soil Cover of Urbanized Territories by Bio-Diagnostics Methods. URL : https:// science-education.ru/ru/article/view?id=26560 (Accessed 01.09.2020) [In Russian].

Gaponyuk, E. I., Malakhov, S. G., 1985. Comprehensive System of Indicators for Ecological Monitoring of Soils. Migration of Pollutants in Soils and Adjacent Environments. Leningrad, Hydrometeoizdat [In Russian].

Gerasimova, M. I., Stroganova, M. N., Mozharova, N. V., Prokofieva, T. V., 2003. Anthropogenic Soils: Genesis, Geography, Recultivation, Ed. G. V. Dobrovolsky. Smolensk, Oykumena [In Russian].

Golovko, E. A., 1971. On Methods for Studying the Biological Activity of Peat Soils, Proceedings of the Scientific Conference on Methods of Microbiological and Biochemical Research of Soils, Kiev, October 28-31, 1971. Kiev. 68-76 [In Russian].

Gorbov, S. N., 2002. Soils of Urban Landscapes in Rostov-on-Don, Their Ecological State and Pollution Assessment : Dis. ... Candidata Biol. Nauk. Rostov-on-Don [In Russian].

Gorbov, S. N., Bezuglova, O. S., 2013. Biological Activity of Urban Territory Soils (Exemplified by Rostov-on-Don), Scientific Journal of KubSAU. 85, 1-15 [In Russian].

Ivashchenko, K. V., Ananyeva, N. D., Vasenev, V. I., Kudeyarov, V. N., Valentini, R., 2014. Biomass and Respiratory Activity of Soil Microorganisms in Anthropogenically Altered Ecosystems (Moscow Oblast), Soil Science. 9, 1077-1088 [In Russian].
Kazeyev, K. Sh., Kolesnikov, S. I., Valkov, V. F., 2004. Soil Biology of Russia's South. Rostov-on-Don, TsVVR [In Russian].

Kotlov, F. V., 1978. Change of the Geological Environment under the Influence of Human Activities. Moscow, Nedra [In Russian].

Lyapina, N. Sh., Myasnikova, I. B., Usova, L. S., Kolosov, E. S., 2019. Determination of Soil Phytotoxicity as a Method for Assessing Its Pollution, Collection of Articles of the II All-Russia Scientific and Practical Conference. 1, 257-260 [In Russian].

Methodological Recommendations, 2008. MP 2.1. 7.2297-07 / Soil. Cleaning of Populated Areas. Household and Industrial Waste. Sanitary Protection of Soil, Bulletin of Normative and Methodological Documents of the State Sanitary and Epidemiological Supervision. 1 (31) [In Russian].

Paz-Ferreiro Jorge, Fu Shenglei, 2016. Biological Indices for Soil Quality Evaluation: Perspectives and Limitations, Land Degradation and Development. 27, 14-25.

Podgornaya, T. I., 2013. Dangerous Natural and Technogenic Geological Processes in the Developed Areas of the Russian Far East. Khabarovsk, Pacific National University [In Russian].

Podgornaya, T. I., Roslikova, V. I., 1999. Influence of Technogenic Geological Processes on Modern Soil Formation in the Cities of the Far East. Vladivostok, Dalnauka [In Russian].

Polyakov, V. Yu., Revutskaya, I. L., 2016. Enzymatic Activity of Upper Diagnostic Horizons in Birobidzhan's Urban Anthropogenic Soils, Vestnik Orenburg State University. 1(189), 95-99 [In Russian].

Pudova, T. M., Shadrina, E. G., 2020. Biotesting of Soil Cover Contamination in Urbanized Areas by Indicators of Germination and Mutagenic Activity of Allium fistulosum L. (Exemplified by Yakutsk). URL: https:// science-education.ru/ru/article/view?id=26346 (Accessed 01.09.2020) [In Russian].

Roslikova, V. I., Matveenko, T. I., 2018. Urbanized Soils of the Amur River Region (on the Example of Khabarovsk). Khabarovsk, Pacific National University [In Russian].

Sharkova, S. Yu., Parfyonova, E. A., Polyanskova, E. A., 2011. Bioindication of the Urban Environment by the State of the Soil Microbial Complex, Ecology and Industry of Russia. 44-47 [In Russian].

Shpis, T. E., 1999. Phytotoxicity of Oils, Factors of Iits Formation, and Reaction of Various Crops to Soil Contamination with Heavy Metals in the Conditions of the Steppe Zone of the Altai Krai : Abstract of 
Dis. ... Candidata Selskokhoz. Nauk. Barnaul [In Russian].

Sorokina, O. I., 2013. Heavy Metals in Landscapes of the City of Ulan-Bator : Autoref. Dis. ... Candidata Geogr. Nauk. Moscow [In Russian].

Stefurak, V. P., Usataya, A. C., Frunze, N. I., Katruk, E. A., 1990. Fermentative Activity of Soils in the Anthropogenic Impact Conditions. Kishinev, Kishinev University [In Russian].
Tkachenko, Ya. D., Pospelova, O. A., Stepanenko, E. E., 2020. Biotesting of Soil Pollution in Industrial Zones of Stavropol. URL: http://ores.su/index.php/-1132013/3522013-02-25-07-51-41 (Accessed 01.09.2020) [In Russian].

Umarov, M. M., 2003. Role of Microorganisms in the Cycle of Chemical Elements in Terrestrial Ecosystems, Structural and Functional Role of Soil in the Biosphere. Moscow, Nauka. 125-139 [In Russian]. 